\title{
Research on Enterprise Financial Risk Early Warning under the Background of Big Data
}

\section{Li Li}

Yunnan Technology and Business University, Kunming, Yunnan, 651700

\author{
Keywords: big data, financial risk, early warning
}

\begin{abstract}
In the context of big data, all sectors of society have ushered in a new revolution, as well as in the financial sector. The purpose of financial management is to promote the sustainable and stable development of enterprises and improve the economic benefits of enterprises. In the era of big data, enterprises must strengthen the transformation of financial management work, start from the challenges brought by big data to traditional financial management of enterprises, and study how financial management can use big data to transform and develop strategies, so as to play a role in the value of financial management to better serve the enterprise.
\end{abstract}

\section{Introduction}

According to the life cycle theory of enterprises, the early stage of SMEs is a start-up period. During this period, because the company lacks sufficient resources, the ability to withstand risks is very poor. Therefore, enterprises at this stage are also very vulnerable because they cannot resist risks. And closed down. In China, there is a very obvious "third year" phenomenon, that is, many enterprises will eventually close down for various reasons within 1-3 years after their establishment. From the perspective of financial management, this type of enterprise is characterized by a continuous decline in profitability until a gradual loss; on the other hand, there is a shortage of funds, and the solvency is gradually reduced, resulting in the inability to pay off the debts due. . Some of these problems cannot be solved by objective conditions, but some are because the managers are not aware of them at the beginning, and they are irreparable after the situation is strict. Therefore, for small and medium-sized enterprises, building a financial risk early warning system and timely discovering problems in their own operations is a major event in their lives and deaths.

\section{Significance of the Establishment of Enterprise Financial Risk Early Warning System}

The data provided by the finance department can accurately reflect the current economic situation of the enterprise, and the relevant management personnel of the enterprise can conduct the next business strategy research according to the information provided by the financial department. At the same time, the relevant management personnel of the enterprise can analyze the financial report, analyze the working status of the enterprise personnel and what benefits it brings to the enterprise. It can be adjusted according to the specialties of the enterprise employees. The financial information is an important auxiliary information for the personnel department to adjust the work position. In the context of the era of big data, all kinds of information within an enterprise can come together, but the information provided by big data is not accurate, but all the information is mixed together, so when the company faces these massive information, finance The risk warning system is able to detect the risks that exist. Ensure that the data provided to the enterprise is more accurate, and provides data for the data used in the internal decision-making of the enterprise.

The era of big data itself is an era in which various information explosions generate a large amount of information data. Enterprises can obtain benefits from massive data, and at the same time bear unprecedented risks. Such opportunities and challenges must be borne by enterprises. Therefore, the market economy has developed faster. The accuracy of information obtained from market changes and the speed of its acquisition, and the effectiveness of timely decision-making based on relevant data have become the key to success. Whether the information obtained by the 
enterprise is effective and whether the decision is correct will bring risks to the corporate finance. In the face of such financial risks, how to deal with and when to deal with it is the key. Therefore, it is necessary to establish a sound financial risk early warning system, which can help enterprises to judge the risk of data and improve the ability of enterprises to deal with financial risks in the era of big data. Promote the rapid development of enterprises and occupy a place in the market economy.

Through the establishment and improvement of the enterprise financial risk early warning system, it can help enterprises to solve various risks arising in the development of the market economy. Flexibility to deal with risks or potential risks within and outside the enterprise. It is conducive to improving the financial management ability of enterprises and ensuring that all financial information provided for the economic development of enterprises is correct and effective. To monitor the flow of funds for enterprises and provide an early warning mechanism for their risks. Once the funds have problems, enterprises can find or prevent financial risks in the first time, helping enterprises to meet financial risks in the shortest time. Solve problems with the least risky solution, minimize the risks and losses that the company may encounter, and maximize the economic benefits. The era of big data has made enterprises more and more likely to face risks, so the establishment of corporate financial risk early warning system is very important.

\section{The Strategy of Enterprise Financial Management Transformation and Development under the Background of Big Data}

In the era of big data, data is no longer just data, but also the wealth of information for good management and decision-making. It enriches the value of data and information to a certain extent. As an internal factor of good business production, it is becoming more and more An important focus of competition in the market. On the other hand, by using the information technology well in the enterprise management and management process, the management model is improved in a form that is more in line with the development of advanced technology, and the management mechanism and management work in the enterprise are more scientific and reasonable. As a major part of the daily operation of the company, the finance department has a great impact on the development of the company and the development of the development plan. It can be seen that the management must have a management philosophy suitable for the development of the era of big data, realize the significance of informationization work for the development of enterprises, and increase investment, and promote the use of information technology in the business of promoting the development of enterprises. . It is manifested in two points: 1 . It has the concept of big data development, and some basic data processing work is completed by information technology, which makes the financial management of enterprises more rational and efficient. 2. Hesitate and abandon the degree of value embodied in the effective development of enterprises, clarify the role of information technology in enterprise decision-making, and deeply explore the opportunities that big data may bring to the development of enterprises, and promote the development model of enterprises. More adapt to the trend of the times and society, so that financial data can better reflect its own value, and contribute to the position of enterprises in the market economy.

The business form of the big data era provides a new path for enterprises to compete in the market. Similarly, the internal management mode and work form must be updated in a new round, especially in financial management. . In order to promote enterprises to adapt to the characteristics of informationization, scale and efficiency in the era of big data, enterprises should constantly reflect on their own work patterns, improve the corresponding management mechanisms, update management techniques, and thus promote the work of all departments of the enterprise. It is able to develop well in the direction of information and intelligence in the era of big data. The specific performance is in three aspects: 1 . Promote the financial department management method to use the data concept as the basic point of innovation and improve the new model of financial management. Enterprises should promote the good use of data management tools in financial management. In the process of financial management, based on the management of new models, the financial work can be efficiently completed, the management of costs is strengthened, and the enterprises are encouraged. The capital chain has a good working condition. 2. Improve the composition of the 
financial management organization system, and promote a clear division of functions within the finance. Enterprises should abolish the obvious division of functions in the traditional form of vulnerabilities, optimize the management structure through intelligent management concepts, clarify the responsibilities of each financial personnel and implement them in a practical way, so that financial information and business information can be Good integration lays a solid foundation for the development of data. 3. Establish and improve the relevant system for financial early warning, and improve the management of budget formulation. In the era of big data, the links between the various parts are close, and the communication is relatively strong. To ensure the integrity of the chain, it is necessary to integrate risk awareness throughout the management process, and promote the information technology to improve the risk warning mechanism and intelligentize it. The means to identify and analyze the risks, so that the management and decision-making of the enterprise can be better carried out. So as far as possible to reduce the damage caused by market competition to the good development of enterprises.

The era of big data has the characteristics of faster information and rapid development. While continuously improving financial management through auxiliary means, it also has higher construction requirements for corresponding facilities. At present, there has been a new round of innovation in the management form of enterprises. By building and improving the corresponding management platform, the internal information and external information are integrated and communicated, and the attitude of the big data era is constantly improved, thereby effectively improving its market competitiveness. . Therefore, enterprises should strengthen the perfection of internal information construction. The specific performance is in three aspects: 1 . Improve the financial management system in line with the development concept of the enterprise, and establish and improve the corresponding information exchange platform. A sound system is the basic condition for continuously promoting management and improvement. Enterprises should effectively improve the rules for data collection and processing, clarify the various processes, and maximize the role that each process can play. Improve the corresponding information exchange platform, so that relevant information and business can lay the foundation for the development of the enterprise. 2. Strengthen the corresponding data system improvement, update and continuously develop and promote financial good management software. When improving software construction, enterprises improve the performance of collecting and analyzing data, reflecting the value behind financial information. 3. Establish a good internal and external environment for financial management and establish a good security barrier for financial information.

The final effect of financial management depends to a large extent on the overall ability of the entire finance team. In order to better meet the challenges of the big data era, we need a team of financial professionals with professional skills and quality at the same time. The extent to which financial management is completed is currently largely dependent on the effectiveness of the financial team's work. It specifically reflects the following four aspects: 1. Promote the effective improvement of the overall quality of financial personnel, and establish a financial information management concept for management. 2. Promote the position of financial personnel in line with the resource optimization configuration requirements, and implement the responsibility of each staff member. 3. Improve the talent entry mechanism and help them master more financial information management technology, cloud technology, database technology, etc., so that financial management staff can meet the arrival of big data era with good quality.

\section{Conclusion}

The professional quality of the relevant personnel in the finance department and the management level of the operation of the entire enterprise have also been put forward. The era of big data has accelerated the development of the market economy. Under this premise, if enterprises want to develop, they must establish a sound financial risk early warning system to help enterprises effectively cope with financial threats that may arise or have emerged. Economic strength, speed up the development, only then can enterprises in the era of big data ride the wind and waves, and obtain more economic benefits. 


\section{References}

[1] Wang Zhiquan. The transformation of big data generation and enterprise financial management [J]. Finance and Accounting .2014(06)

[2] He Xuemei. Research on Financial Management Transformation of Enterprise Groups in Big Data Era [J].Legal System and Economy. 2014 (05)

[3] ang Hongming. New Trends in Financial Management of Enterprise Groups under the Background of Big Data [J].Management Observation.2014 (11)

[4] Cheng Ping, Chen Shan. Analysis of financial management of small and micro enterprises based on cloud accounting in the era of big data [J]. Friends of Accounting. 2016(06)

[5] Wu Bingbing, Xu Weimin, Xu Helong, Zhang Yu. Research on the development strategy of science and technology service industry under the background of big data [J].Science and Technology Management Research. 2015(10) 